\title{
Penerapan Video Pembelajaran IPA untuk Meningkatkan Hasil Belajar Siswa Kelas V di SDN Balongsari I/500 Surabaya
}

\author{
Margaretha Ordo Servitri \\ SDN Balongsari I/500 Surabaya \\ e-mail: margaretha.ordo.s@gmail.com
}

\begin{abstract}
Abstrak
Penelitian ini bertujuan untuk ((1) Mendeskripsikan pelaksanaan pembelajaran dengan penerapan video pembelajaran IPA; dan (2) Mendeskripsikan peningkatan ketuntasan hasil belajar siswa kelas $\mathrm{V}$ secara klasikal setelah penerapan video pembelajaran IPA. Metode penelitian yang digunakan adalah penelitian tindakan kelas (PTK) dengan subjek penelitian siswa kelas V-C di SDN Balongsari I/500 Surabaya yang berjumlah 35 siswa. Teknik pengumpulan data yang digunakan adalah observasi dan tes dengan instrumen lembar observasi dan lembar tes hasil belajar. Pada akhirnya penelitian ini dilaksanakan hanya sampai 2 siklus. Adapun hasil penelitian menunjukkan bahwa (1) Pelaksanaan pembelajaran dengan penerapan video pembelajaran IPA mengalami peningkatan dari siklus 1 sebesar $76 \%$ ke siklus 2 sebesar $82 \%$; dan (2) Terjadi peningkatan hasil belajar siswa kelas $\mathrm{V}$ setelah penerapan video pembelajaran IPA dari siklus 1 sebesar $74 \%$ ke siklus 2 sebesar $91 \%$.
\end{abstract}

Kata kunci: video pembelajaran, IPA, hasil belajar

\begin{abstract}
This study aims to (1) describe the implementation of learning with the application of science learning videos; and (2) Describe the improvement in the learning outcomes of fifth grade students after the application of science learning videos. The research method used is classroom action research (CAR) with 35 students as the subject of class V-C at SDN Balongsari $\mathrm{I} / 500$ Surabaya. The data collection technique used was observation and tests with the instrument of observation sheets and learning outcomes test sheets. In the end, this research was carried out only for 2 cycles. The research results show that (1) the implementation of learning with the application of science learning videos has increased from cycle 1 of $76 \%$ to cycle 2 of $82 \%$; and (2) There was an increase in the learning outcomes of fifth graders after the application of science learning videos from cycle 1 of $74 \%$ to cycle 2 of $91 \%$.
\end{abstract}

Keywords: learning video, science, learning outcomes

\section{PENDAHULUAN}

Pendidikan merupakan hal yang amat sangat penting dalam rangka mempersiapkan generasi penerus bangsa dan sumber daya manusia (SDM) yang berkualitas. Melalui pelaksanaan pembelajaran, pendidikan mampu berperan sebagai wadah untuk meningkatkan kualitas SDM. Melalui pembelajaran pula diharapkan akan mampu memberikan kedewasaan kepada setiap individu. Pendidikan sendiri merupakan upaya yang dilakukan secara sadar dalam rangka membimbing dan mengarahkan perkembangan anak ke arah dewasa, sehingga melalui pendidikan diharapkan mampu mempersiapkan SDM yang lebih berkualitas dan mengembangkan setiap individu ke arah pendewasaan (Jamaris, 2013).

Di awal pandemi Covid-19 bulan Maret tahun 2020, Kemendikbud mengeluarkan kebijakan melalui Surat Edaran Nomor 4 Tahun 2020 tentang Pelaksanaan Pendidikan Dalam Masa Darurat Penyebaran Corona Virus Disease. Kebijakan tersebut merupakan 
langkah strategis yang diambil di masa darurat Covid-19 dengan tetap sejalan sesuai visi misi dan tujuan pendidikan, salah satunya adalah penerapan sistem pembelajaran daring. Menurut Yuliani et al., (2020, p. 2), pembelajaran daring merupakan suatu konsep pembelajaran yang membuat peserta didik dapat belajar kapan pun dan di mana pun dengan memanfaatkan perangkat teknologi seperti smartphone, tablet, laptop, atau komputer. Sedangkan Rigianti mengemukakan jika cara belajar dengan pemanfaatan perangkat elektronik, khususnya jaringan internet, merupakan pembelajaran daring. Dengan kata lain, pembelajaran daring ini memiliki ketergantungan terhadap oleh akses internet (2020, p. 298). Berdasarkan pendapat ahli tersebut, maka dapat disimpulkan jika pembelajaran daring merupakan pembelajaran dengan pemanfaatan peranti elektronik, seperti smartphone, tablet, laptop, atau komputer yang dapat terkoneksi ke internet sehingga membuat peserta didik bisa belajar di mana saja dan kapan saja dalam menerima penyampaian materi dari guru.

Namun demikian adanya, dalam pelaksanaan pembelajaran daring justru menimbulkan permasalahan baru yang peneliti alami, salah satunya adalah ketidaktepatan penggunaan media pembelajaran yang berimbas pada pencapaian hasil belajar siswa. Peneliti menganggap jika pemanfaatan teknologi dalam pembelajaran daring harus diimbangi dengan inovasi pada pelaksanaan pembelajarannya, salah satunya dengan pemanfaatan video sebagai sebuah media pembelajaran. Penggunaan media pembelajaran adalah sebagai sarana meningkatkan minat belajar, pemilihan media juga disesuaikan dengan kondisi siswa dan hal yang dekat dengan kehidupan siswa (Febriani, 2017).

Pembelajaran di Sekolah Dasar (SD) sendiri terdiri dari beberapa mata pelajaran yang harus dipelajari oleh siswa, salah satunya adalah mata pelajaran IImu Pengetahuan Alam (IPA), di mana pelajaran IPA ini turun berperan penting dalam upaya mewujudkan generasi emas masa depan. IPA merupakan rumpun ilmu yang memiliki karakteristik khusus, yaitu mempelajari fenomena alam yang faktual, baik berupa kenyataan atau kejadian dan hubungan sebab-akibatnya (Wisudawati \& Sulistyowati, 2014). Berdasarkan cakupan materi yang diajarkan dalam pembelajaran IPA di SD, salah satu di antaranya dapat dilakukan dengan memanfaatkan media pembelajaran yang tepat dan sesuai dengan tingkat perkembangan siswa SD.

Siswa SD berada pada rentang usia antara 6-12 tahun. Pada masa ini, siswa mengalami transisi yang ditandai dengan berakhirnya masa kanak-kanak, yaitu suatu masa ketika anak tumbuh dan berkembang dalam semua bidang dan mulai pada suatu fase perkembangan yang lebih perlahan-lahan. Pada fase ini, terjadi proses adaptasi baru dalam memperoleh pengetahuan yang ditentukan juga oleh fase kognitifnya (Baharuddin \& Wahyuni, 2015). Menurut Bruner dalam Aisyah et al., (2010), belajar merupakan sebuah proses aktif yang dapat memungkinkan manusia untuk menemukan hal-hal baru di luar informasi yang diberikan kepada dirinya. Ada tiga proses kognitif yang terjadi dalam belajar, yaitu proses perolehan informasi baru, proses mentransformasikan informasi yang diterima, dan menguji relevansi dan ketepatan pengetahuan. Teori belajar Bruner terdiri dari tiga tahap, yaitu (1) Tahap enaktif, merupakan tahap pembelajaran yang penyajiannya dilakukan melalui benda benda konkrit atau menggunakan situasi yang nyata; (2) Tahap ikonik, merupakan pembelajaran yang penyajiannya direpresentasikan dalam sebuah bentuk bayangan visual yang menggambarkan situasi konkret; dan (3) Tahap simbolik, merupakan pembelajaran yang direpresentasikan dalam bentuk simbol atau lambang yang abstrak.

Beberapa strategi yang dapat dilakukan guru dalam mengajar siswa dengan pemikiran operasional konkret di antaranya adalah mendorong siswa untuk menemukan konsep dan prinsip, melibatkan siswa dalam tugas-tugas operasional, merencanakan aktivitas di mana siswa dapat berlatih konsep mengurutkan hierarki naik atau turun, mengajak siswa bekerja kelompok dan saling bertukar pikiran, memastikan materi dapat merangsang siswa untuk mengajukan pertanyaan, menggunakan alat bantu visual atau peraga (Santrock, 2013).

Alat bantu visual/peraga atau yang biasa disebut dengan istilah media pembelajaran. Media sendiri digunakan sebagai perantaran agar penyampaian materi pembelajaran dapat 
berjalan dengan baik. Hal ini tidak lepas dari makna media itu sendiri sebagai perantara atau penyalur. Terlebih lagi media pembelajaran memang berfungsi untuk meningkatkan rangsangan belajar siswa (Ramdhani et al., 2015). Rangsangan belajar yang baik akan memberikan pengalaman belajar yang efektif dengan mempertimbangkan kelebihan dan kekurangan media yang digunakan. Secara umum terdapat tiga unsur pokok media, yaitu suara, visual, dan gerak (Susilana \& Riyana, 2008).

Pemilihan atau penggabungan media sangatlah bergantung dari karakteristik materi dan karakeristik peserta didik yang dibelajarkan, antara lain media visual, audio, audio visual, multimedia dan realita. Karakteristik peserta didik usia sekolah dasar yang sejatinya dalam hierarki Piaget masih dalam tahap operasional konkret (Kurniawan, 2015). Oleh sebab itu, pada tahap ini masih sangat dibutuhkan peran media yang membantu transformasi pengetahuan secara lebih nyata. Terkait dengan karakteristik materi pembelajaran, pemilihan media harus sesuai dengan materi yang diajarkan (Abdullah, 2017). Salah satu contoh nyata pelaksanaannya adalah pada pembelajaran IPA, karena tentunya media yang digunakan harus mampu menjembatani konstruksi pengetahuan yang benarbenar nyata, salah satunya dengan menggunakan media video.

Media video adalah alat untuk menyampaikan materi pembelajaran melalui tayangan gambar bergerak yang diproyeksikan membentuk karakter yang sama dengan objek aslinya (Susilana \& Riyana, 2008). Penggunaan media pembelajaran video mampu memberikan respon positif dari siswa karena kegiatan yang menarik siswa untuk ditonton secara saksama disertai dengan rasa keingitahuan sehingga membuat siswa termotivasi untuk belajar dan mampu meningkatkan pemahamannya terhadap materi pelajaran yang disampaikan (Mimi, 2016). Video pembelajaran sangatlah tepat jika digunakan dalam pembelajaran IPA (Yunita \& Wijayanti, 2017). Hal itu dikarenakan tidak semua materi dapat digambarkan secara nyata serta membutuhkan proses yang lama untuk mengamatinya. Oleh sebab itu guru perlu media atau alat bantu untuk bisa menggambarkannya kepada siswa agar siswa lebih mudah memahami materi IPA tersebut. Hal ini diperkuat juga dengan pendapat Setiawan (2017), yakni penggunaan media dimaksudkan sebagai perantara untuk menciptakan suatu kondisi lingkungan belajar yang dapat menunjang tercapainya tujuan pembelajaran yang diwujudkan dalam bentuk hasil belajar siswa.

Beberapa penelitian juga menunjukkan bahwa penggunaan media video dalam pembelajaran IPA dapat meningkatkan pemahaman siswa. Di antaranya penelitian yang dilakukan oleh Risky (2019) menyatakan bahwa penggunaan media video dalam pembelajaran IPA di kelas $\mathrm{V}$ SD Muhammadiyah 1 Tulungagung tampak dapat menumbuhkan perhatian dan menambah kemudahan siswa dalam memahami materi IPA. Terlebih lagi melalui penggunaan media video dalam pembelajaran IPA mendapat respon positif dari guru dan siswa kelas $\mathrm{V}$ di SD Muhammadiyah 1 Tulunggagung.

Begitu juga dengan Penelitian yang dilakukan oleh Febrian (2017) bahwa terdapat pengaruh positif pada pembelajaran IPA yang menggunakan media video dibandingkan dengan pembelajaran IPA yang menggunakan media gambar terhadap motivasi belajar dan hasil belajar kognitif pembelajaran IPA.

Berdasarkan paparan di atas, peneliti tertarik melakukan penelitian tindakan kelas (PTK) dengan judul "Penerapan Video Pembelajaran IPA untuk Meningkatkan Hasil Belajar Siswa Kelas V di SDN Balongsari I/500 Surabaya". Video pembelajaran IPA peneliti fokuskan pada tema Makanan Sehat dan subtema Pentingnya Makanan Sehat bagi Tubuh dan Pentingnya Menjaga Asupan Makanan Sehat. Adapun tujuan dari PTK yang dilakukan adalah (1) Mendeskripsikan pelaksanaan pembelajaran dengan penerapan video pembelajaran IPA; dan (2) Mendeskripsikan peningkatan ketuntasan hasil belajar siswa kelas $\mathrm{V}$ secara klasikal setelah penerapan video pembelajaran IPA.

\section{METODE PENELITIAN}

Jenis penelitian yang dilakukan merupakan penelitian tindakan kelas (PTK). PTK merupakan suatu penelitian yang berorientasi untuk memperbaiki suatu keadaan atau permasalahan praktis yang dihadapi termasuk dalam konteks pendidikan, khususnya 
pembelajaran di kelas yang bertujuan untuk meningkatkan mutu pendidikan (Setiawan, 2017).

Arikunto dkk. (2014) dalam bukunya mengemukakan bahwa pada setiap siklus PTK yang dilaksanakan terdiri atas empat tahapan, yaitu perencanaan, pelaksanaan, pengamatan dan refleksi. Hal ini merupakan salah satu ciri penelitian tindakan kelas. Berikut adalah gambar dari siklus PTK.

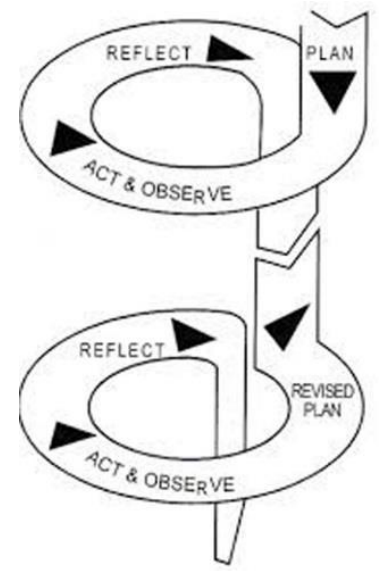

\section{Gambar 1. Siklus PTK (Prihantoro \& Hidayat, 2019)}

Tahapan perencanaan yang dilakukan yaitu menganalisis kurikulum 2013 untuk mengetahui kompetensi inti (KI) dan kompetensi dasar (KD), menyusun perangkat pembelajaran (RPP, LKS, THB, materi, serta membuat media video pembelajaran IPA) dan instrumen penelitian (lembar pengamatan penerapan video pembelajaran IPA), serta melakukan validasi perangkat pembelajaran dan instrumen penelitian. Pada tahap ini peneliti juga menentukan pengamat dari rekan sejawat.

Tahap pelaksanaan tindakan siklus 1 yaitu peneliti akan menerapkan apa yang sudah diskenariokan dalam tahap perencanaan, yaitu menerapkan video pembelajaran IPA selama pembelajaran berlangsung dalam sistem dalam jaringan (daring) melalui Teams sesuai dengan langkah-langkah yang disusun dalam RPP.

Tahap pengamatan atau observasi siklus 1 dilakukan orang pengamat dari rekan sejawat yang sudah peneliti tunjuk. Pengamat melakukan pencatatan terhadap penerapan video pembelajaran IPA selama pembelajaran berlangsung dalam sistem daring. Tahap ini dilakukan secara bersamaan dengan tahap pelaksanaan.

Tahap refleksi yaitu tahapan diskusi antara peneliti dan pengamat terhadap hasil pelaksanaan yang berkaitan dengan proses dan dampak tindakan perbaikan yang diberikan, serta rencana bagi tindakan selanjutnya.

Penelitian ini berlokasi di SDN Balongsari I/500 Surabaya dengan subjek penelitian adalah siswa kelas V-C yang berjumlah 35 siswa di semester gasal tahun ajaran 2021/2022.

Teknik pengumpulan data yang digunakan ada dua teknik, yaitu observasi dan tes. Observasi adalah metode atau cara menghimpun data yang dilakukan dengan mengadaan pengamatan atau pencatatan secara sistematis terhadap keadaan yang sedang dijadikan sebagai sasaran pengamatan (Mania, 2008). Dalam penelitian ini, observasi dilakukan untuk mendapatkan data pelaksanaan pembelajaran dengan penerapan video pembelajaran IPA dengan rincian 4 (sangat baik), 3 (baik), 2 (cukup baik), dan 1 (kurang baik). Adapun tes merupakan alat untuk mengevaluasi hasil belajar yang digunakan dalam rangka pengukuran dan penilaian di bidang pendidikan (Kadir, 2015). Dalam penelitian ini, tes digunakan untuk mendapatkan data hasil belajar siswa setelah penerapan video pembelajaran IPA.

Teknik analisis data yang akan peneliti lakukan yaitu pelaksanaan pembelajaran dengan penerapan video pembelajaran IPA dan ketuntasan hasil belajar siswa secara klasikal. Adapun rumusnya adalah sebagai berikut. 
Rumus analisis data persentase pelaksanaan pembelajaran dengan penerapan video pembelajaran IPA (Penelitian et al., 2013).

$$
P=\frac{f}{N} \times 100 \%
$$

Keterangan:

$$
\begin{aligned}
& P \quad=\text { Persentase. } \\
& f \quad=\text { Jumlah skor yang sedang } \\
& \text { dicari persentasenya. } \\
& N=\text { = Jumlah banyaknya skor } \\
& \text { maksimal. }
\end{aligned}
$$

Rumus analisis data persentase ketuntasan hasil belajar siswa secara klasikal (Sukardi, 2003).

Keterangan:

$$
P=\frac{\sum X}{N} \times 100 \%
$$

$$
P \quad=\text { Persentase. }
$$

$\sum X \quad=$ Jumlah siswa yang

$$
\text { mendapat nilai } \geq 75 \text {. }
$$

$N \quad=$ Jumlah seluruh siswa.

Adapun pelaksanaan penelitian ini dikatakan berhasil jika (1) Pelaksanaan pembelajaran dengan penerapan video pembelajaran IPA mencapai persentase $\geq 80 \%$; dan (2) Ketuntasan hasil belajar siswa kelas $\mathrm{V}$ secara klasikal setelah penerapan video pembelajaran IPA mencapai persentase $\geq 80 \%$.

\section{HASIL DAN PEMBAHASAN Hasil Penelitian}

Peneliti terlebih dahulu melakukan stdui pendahuluan yang bertujuan untuk mencari tahu masalah pembelajaran yang akan digunakan sebagai acuan dalam melakukan perencanaan di siklus 1 , yaitu ketidaktepatan penggunaan media pembelajaran yang peneliti lakukan saat pembelajaran daring, sehingga berimbas pada pencapaian hasil belajar siswa. Kondisi tersebut membuat peneliti merasa perlu jika pemanfaatan teknologi dalam pembelajaran daring harus diimbangi dengan inovasi pada pelaksanaan pembelajarannya, salah satunya dengan pemanfaatan video sebagai sebuah media pembelajaran.

Berdasarkan hal di atas, peneliti ingin menerapkan video pembelajaran IPA untuk meningkatkan hasil belajar siswa. Berikut adalah penjabaran secara lengkap deskripsi dari siklus 1.

\section{Siklus 1}

Tujuan dilaksanakannya siklus 1 adalah untuk menindaklanjuti hasil dari studi pendahuluan. Berikut ini adalah penjabarannya.

\section{Perencanaan}

Hal-hal yang dilakukan dalam tahap perencanaan adalah (1) Menganalisis Kurikulum 2013 untuk mengetahui kompetensi inti (KI) dan kompetensi dasar (KD), sehingga ditentukan pada subtema Pentingnya Makanan Sehat bagi Tubuh; (2) Menyusun perangkat pembelajaran yang meliputi RPP, LKS, THB, materi, serta membuat media video pembelajaran IPA tentang pentingnya makanan sehat bagi tubuh; (3) Menyusun instrumen penelitian yang meliputi lembar pengamatan pelaksanaan pembelajaran dengan penerapan video pembelajaran IPA; (4) Melakukan validasi perangkat pembelajaran dan instrumen penelitian kepada Irma Nur Indriana, S.Pd.; (6) Merevisi perangkat pembelajaran dan instrumen penelitian; serta (7) Menentukan pengamat dari rekan sejawat, yaitu Lilik Eko Nalise, S.Pd. dan Jelita Widjanarko S.Pd. sekaligus akan melakukan penyamaan persepsi tentang waktu pelaksanaan tindakan.

2. Pelaksanaan Tindakan

Pelaksanaan proses pembelajaran daring pada siklus I ini dilaksanakan hari Senin, 4 Oktober 2021 selama 2 x 35 menit. Berikut merupakan langkah-langkah pembelajara yang dilakukan (1) Menyampaikan tujuan pembelajaran dan mempersiapkan siswa. Pada 
tahap ini tujuan pembelajaran yang peneliti sampaikan adalah tentang pentingnya makanan sehat bagi tubuh. Selain itu peneliti juga mempersiapkan siswa dengan melakukan tanya jawab yang memiliki relevansi dengan subtema yang akan dipelajari, yaitu "Anak-anak, apakah kalian tadi sudah sarapan pagi sebelum memulai pembelajaran?", "Lauk apa yang kalian buat sarapan?", "Apakah lauk tersebut sudah mencerminkan makanan sehat?", dsb.; (2) Mendemonstrasikan pengetahuan dan keterampilan. Pada tahap ini, peneliti menyampaikan pengetahuan tentang pentingnya makanan sehat bagi tubuh melalui video pembelajaran IPA; (3) Membimbing pelatihan. Di tahap ini peneliti memberikan siswa latihan soal tentang pentingnya makanan sehat bagi tubuh. Selain itu peneliti juga melakukan pengawasan dan pembimbingan kepada setiap siswa melalui tanya jawab; (4) Mengecek pemahaman dan memberikan umpan balik. Peneliti meminta beberapa siswa untuk memaparkan hasil kerjanya di hadapan temantemannya sebagai bentuk pengecekan pemahaman siswa. Di samping itu peneliti juga meluruskan jika terjadi kesalahan konsep oleh siswa; serta terakhir (5) Memberikan kesempatan untuk pelatihan lanjutan dan penerapan. Pada tahap ini peneliti memberikan sebuah tugas lanjutan kepada siswa dengan meminta untuk mempelajari kembali pentingnya makanan sehat bagi tubuh.

3. Pengamatan

Hasil rata-rata pengamatan dari dua pengamat, yakni Lilik Eko Nalise, S.Pd. dan Jelita Widjanarko S.Pd., terhadap pelaksanaan pembelajaran dengan penerapan video pembelajaran IPA disajikan dalam tabel berikut ini.

Tabel 1. Pelaksanaan Pembelajaran dengan Penerapan Video Pembelajaran IPA Siklus 1

\begin{tabular}{clcc}
\hline No & Aspek yang Diamati & Rata-rata & $\%$ \\
\hline 1 & $\begin{array}{l}\text { Menyampaikan tujuan } \\
\text { pembelajaran dan } \\
\text { mempersiapkan siswa. }\end{array}$ & 4,5 & 90 \\
\hline 2 & $\begin{array}{l}\text { Mendemonstra-sikan pengetahuan } \\
\text { dan keterampilan. }\end{array}$ & 4 & 80 \\
\hline 3 & Membimbing pelatihan. & 3,5 & 70 \\
\hline $4 \quad \begin{array}{l}\text { Mengecek pemahaman dan } \\
\text { memberikan umpan balik. }\end{array}$ & 3 & 60 \\
\hline $5 \quad \begin{array}{l}\text { Memberikan kesempatan untuk } \\
\text { pelatihan lanjutan dan } \\
\text { penerapan. }\end{array}$ & 4 & 80 \\
\hline Jumlah & 19 & 76 \\
\hline Rata-rata & 3,8 & \\
\hline
\end{tabular}

Kategori:

$80 \%-100 \% \quad$ sangat baik

$66 \%-79 \%$ baik

$56 \%-65 \%$ cukup

$0 \%-55 \%$ kurang

Berdasarkan tabel 1 di atas, diperoleh data hasil pelaksanaan pembelajaran dengan penerapan video pembelajaran IPA memperoleh skor rata-rata 3,8 dengan persentase $76 \%$ dan dikategorikan baik.

Tabel 2. Hasil Belajar Siswa Kelas V Siklus 1

\begin{tabular}{clcc}
\hline No & Inisial Siswa & Nilai & Keterangan \\
\hline 1 & AND & 75 & T \\
\hline 2 & AR & 78 & T \\
\hline 3 & BKR & 80 & T \\
\hline 4 & BAS & 77 & T \\
\hline
\end{tabular}




\begin{tabular}{|c|c|c|c|}
\hline No & Inisial Siswa & Nilai & Keterangan \\
\hline 5 & CAP & 74 & TT \\
\hline 6 & DDL & 85 & $\mathrm{~T}$ \\
\hline 7 & DVC & 76 & $\mathrm{~T}$ \\
\hline 8 & DS & 70 & TT \\
\hline 9 & DR & 81 & $\mathrm{~T}$ \\
\hline 10 & FAV & 77 & $\mathrm{~T}$ \\
\hline 11 & $\mathrm{I}$ & 75 & $T$ \\
\hline 12 & IBF & 80 & $\mathrm{~T}$ \\
\hline 13 & JV & 73 & TT \\
\hline 14 & JIN & 76 & $\mathrm{~T}$ \\
\hline 15 & KBN & 68 & TT \\
\hline 16 & $\mathrm{KZA}$ & 86 & $\mathrm{~T}$ \\
\hline 17 & $\mathrm{MU}$ & 81 & $\mathrm{~T}$ \\
\hline 18 & MAP & 82 & $\mathrm{~T}$ \\
\hline 19 & MAI & 69 & TT \\
\hline 20 & MAA & 78 & $\mathrm{~T}$ \\
\hline 21 & MAZA & 72 & TT \\
\hline 22 & $\mathrm{MC}$ & 77 & $T$ \\
\hline 23 & NSS & 75 & $\mathrm{~T}$ \\
\hline 24 & NAO & 71 & TT \\
\hline 25 & OBA & 80 & $\mathrm{~T}$ \\
\hline 26 & RMAF & 87 & $T$ \\
\hline 27 & SZM & 76 & $\mathrm{~T}$ \\
\hline 28 & TNSR & 79 & $T$ \\
\hline 29 & SO & 70 & TT \\
\hline 30 & SPM & 77 & $\mathrm{~T}$ \\
\hline 31 & AHKA & 75 & $\mathrm{~T}$ \\
\hline 32 & $A D$ & 78 & $\mathrm{~T}$ \\
\hline 33 & JCRM & 74 & TT \\
\hline 34 & RGUA & 77 & $\mathrm{~T}$ \\
\hline 35 & ANJL & 80 & $\mathrm{~T}$ \\
\hline \multicolumn{2}{|c|}{ Jumlah } & 2689 & \\
\hline \multicolumn{2}{|c|}{ Rata-rata } & 76,8 & \\
\hline
\end{tabular}

Keterangan:

$\mathrm{T}=$ Tuntas

$\mathrm{TT}=$ Tidak tuntas

Berdasarkan tabel 2 di atas, diperoleh data ketuntasan hasil belajar siswa kelas $\mathrm{V}$ secara klasikal setelah penerapan video pembelajaran IPA dengan rincian 26 siswa atau $74 \%$ mencapai KKM dan delapan siswa atau 26\% tidak mencapai KKM. Sedangkan nilai rata-rata klasikal adalah 76,8.

4. Refleksi

Berdasarkan hasil refleksi siklus 1 ditemukan kekurangan pada aspek mengecek pemahaman dan memberikan umpan balik, sehingga diperlukan upaya perbaikan yang perlu dilakukan di siklus 2, yaitu peneliti harus lebih teliti dalam memberikan pembenaran jika terjadi kesalahan konsep oleh siswa, sehingga apa yang dipelajari oleh siswa benarbenar tepat.

\section{Siklus 2}

Tujuan diadakannya siklus 2 adalah untuk memperbaiki kekurangan yang ditemukan pada siklus 1. Berikut ini adalah penjabarannya.

1. Perencanaan 
Hal-hal yang dilakukan dalam tahap perencanaan adalah (1) Menganalisis Kurikulum 2013 untuk mengetahui kompetensi inti (KI) dan kompetensi dasar (KD), sehingga ditentukan pada subtema Pentingnya Menjaga Asupan Makanan Sehat; (2) Menyusun perangkat pembelajaran yang meliputi RPP, LKS, THB, materi, serta membuat media video pembelajaran IPA tentang pentingnya menjaga asupan makanan sehat. Penyusunan RPP di dalamnya ditekankan pada upaya peneliti dalam memberikan pembenaran jika terjadi kesalahan konsep oleh siswa agar apa yang dipelajari oleh siswa benar-benar tepat; (3) Menyusun instrumen penelitian yang meliputi lembar pengamatan pelaksanaan pembelajaran dengan penerapan video pembelajaran IPA; (4) Melakukan validasi perangkat pembelajaran dan instrumen penelitian kepada Irma Nur Indriana, S.Pd.; (6) Merevisi perangkat pembelajaran dan instrumen penelitian; serta (7) Menentukan pengamat dari rekan sejawat, yaitu Lilik Eko Nalise, S.Pd. dan Jelita Widjanarko S.Pd. sekaligus akan melakukan penyamaan persepsi tentang waktu pelaksanaan tindakan.

2. Pelaksanaan Tindakan

Pelaksanaan proses pembelajaran daring pada siklus I ini dilaksanakan hari Senin, 11 Oktober 2021 selama 2 × 35 menit. Berikut merupakan langkah-langkah pembelajara yang dilakukan (1) Menyampaikan tujuan pembelajaran dan mempersiapkan siswa. Pada tahap ini tujuan pembelajaran yang peneliti sampaikan adalah tentang pentingnya menjaga asupan makanan sehat. Selain itu peneliti juga mempersiapkan siswa dengan melakukan tanya jawab yang memiliki relevansi dengan subtema yang akan dipelajari, yaitu "Anak-anak, tahukah kalian apa saja yang termasuk makanan sehat?", "Apakah kalian tahu jika tubuh kita kekurangan asupan makanan sehat?", dsb.; (2) Mendemonstrasikan pengetahuan dan keterampilan. Pada tahap ini, peneliti menyampaikan pengetahuan tentang pentingnya menjaga asupan makanan sehat melalui video pembelajaran IPA; (3) Membimbing pelatihan. Di tahap ini peneliti memberikan siswa latihan soal tentang pentingnya menjaga asupan makanan sehat. Selain itu peneliti juga melakukan kontrol/pengawasan dan pembimbingan kepada setiap siswa melalui tanya jawab; (4) Mengecek pemahaman dan memberikan umpan balik. Peneliti meminta beberapa siswa untuk memaparkan hasil kerjanya di hadapan teman-temannya sebagai bentuk pengecekan pemahaman siswa. Di samping itu peneliti juga meluruskan jika terjadi kesalahan konsep oleh siswa; serta terakhir (5) Memberikan kesempatan untuk pelatihan lanjutan dan penerapan. Pada tahap ini peneliti memberikan sebuah tugas lanjutan kepada siswa dengan meminta untuk mempelajari kembali pentingnya menjaga asupan makanan sehat.

3. Pengamatan

Hasil rata-rata pengamatan dari dua pengamat, yakni Lilik Eko Nalise, S.Pd. dan Jelita Widjanarko S.Pd., terhadap pelaksanaan pembelajaran dengan penerapan video pembelajaran IPA disajikan pada tabel berikut ini.

Tabel 3. Pelaksanaan Pembelajaran dengan Penerapan Video Pembelajaran IPA Siklus 2

\begin{tabular}{clcc}
\hline No & Aspek yang Diamati & Rata-rata & $\%$ \\
\hline 1 & $\begin{array}{l}\text { Menyampaikan tujuan } \\
\text { pembelajaran dan } \\
\text { mempersiapkan siswa. }\end{array}$ & 4,5 & 90 \\
\hline 2 & $\begin{array}{l}\text { Mendemonstra-sikan pengetahuan } \\
\text { dan keterampilan. }\end{array}$ & 4,5 & 90 \\
\hline 3 & Membimbing pelatihan. & 3,5 & 70 \\
\hline 4 & $\begin{array}{l}\text { Mengecek pemahaman dan } \\
\text { memberikan umpan balik. }\end{array}$ & 4 & 80 \\
\hline 5 & $\begin{array}{l}\text { Memberikan kesempatan untuk } \\
\text { pelatihan lanjutan dan } \\
\text { penerapan. }\end{array}$ & 4 & 80 \\
\hline
\end{tabular}


Kategori:

\begin{tabular}{lcc}
\hline No Aspek yang Diamati & Rata-rata & $\%$ \\
\hline Jumlah & 20,5 & 82 \\
\hline Rata-rata & 4,1 & \\
\hline
\end{tabular}

$80 \%-100 \% \quad$ sangat baik

$66 \%-79 \%$ baik

$56 \%-65 \%$ cukup

$0 \%-55 \%$ kurang

Berdasarkan tabel 3 di atas, diperoleh data hasil pelaksanaan pembelajaran dengan penerapan video pembelajaran IPA memperoleh skor rata-rata 4,1 dengan persentase $82 \%$ dan dikategorikan sangat baik.

Tabel 4. Hasil Belajar Siswa Kelas V Siklus 2

\begin{tabular}{clcc}
\hline No & Inisial Siswa & Nilai & Keterangan \\
\hline 1 & AND & 75 & $\mathrm{~T}$ \\
\hline 2 & AR & 77 & $\mathrm{~T}$ \\
\hline 3 & BKR & 82 & $\mathrm{~T}$ \\
\hline 4 & BAS & 79 & $\mathrm{~T}$ \\
\hline 5 & CAP & 77 & $\mathrm{~T}$ \\
\hline 6 & DDL & 84 & $\mathrm{~T}$ \\
\hline 7 & DVC & 78 & $\mathrm{~T}$ \\
\hline 8 & DS & 75 & $\mathrm{~T}$ \\
\hline 9 & DR & 80 & $\mathrm{~T}$ \\
\hline 10 & FAV & 77 & $\mathrm{~T}$ \\
\hline 11 & $\mathrm{I}$ & 76 & $\mathrm{~T}$ \\
\hline 12 & IBF & 82 & $\mathrm{~T}$ \\
\hline 13 & JV & 76 & $\mathrm{~T}$ \\
\hline 14 & JIN & 77 & $\mathrm{~T}$ \\
\hline 15 & KBN & 71 & $\mathrm{TT}$ \\
\hline 16 & KZA & 85 & $\mathrm{~T}$ \\
\hline 17 & MU & 82 & $\mathrm{~T}$ \\
\hline 18 & MAP & 81 & $\mathrm{~T}$ \\
\hline 19 & MAI & 73 & $\mathrm{TT}$ \\
\hline 20 & MAA & 79 & $\mathrm{~T}$ \\
\hline 21 & MAZA & 75 & $\mathrm{~T}$ \\
\hline 22 & MC & 76 & $\mathrm{~T}$ \\
\hline 23 & NSS & 77 & $\mathrm{~T}$ \\
\hline 24 & NAO & 75 & $\mathrm{~T}$ \\
\hline 25 & OBA & 81 & $\mathrm{~T}$ \\
\hline 26 & RMAF & 89 & $\mathrm{~T}$ \\
\hline 27 & SZM & 77 & $\mathrm{~T}$ \\
\hline 28 & TNSR & 78 & $\mathrm{~T}$ \\
\hline 29 & SO & 74 & $\mathrm{TT}$ \\
\hline 30 & SPM & 78 & $\mathrm{~T}$ \\
\hline 31 & AHKA & 77 & $\mathrm{~T}$ \\
\hline 32 & AD & 80 & $\mathrm{~T}$ \\
\hline 33 & JCRM & 77 & $\mathrm{TT}$ \\
\hline 34 & RGUA & 76 & $\mathrm{~T}$ \\
\hline 35 & ANJL & 81 & $\mathrm{~T}$ \\
\hline Jumlah & 2737 & \\
\hline Rata-rata & 78,2 & \\
\hline & & & \\
\hline
\end{tabular}


Keterangan:

$\mathrm{T}=$ Tuntas

$\mathrm{TT}=$ Tidak tuntas

Berdasarkan tabel 4 di atas, diperoleh data ketuntasan hasil belajar siswa kelas $\mathrm{V}$ secara klasikal setelah penerapan video pembelajaran IPA dengan rincian 32 siswa atau $91 \%$ mencapai KKM dan empat siswa atau 9\% tidak mencapai KKM. Sedangkan nilai rata-rata klasikal adalah 78,2.

4. Refleksi

Berdasarkan hasil refleksi siklus 2 peneliti tidak menemui kendala berarti. Hal tersebut didukung juga oleh data pencapaian pelaksanaan pembelajaran dengan penerapan video pembelajaran IPA dan ketuntasan hasil belajar siswa kelas $\mathrm{V}$ secara klasikal setelah penerapan video pembelajaran IPA yang telah melebihi indikator keberhasilan, yakni $\geq 80 \%$.

\section{PEMBAHASAN}

Berdasarkan hasil penelitian yang telah dilakukan pada pelaksanaan pembelajaran dengan penerapan video pembelajaran IPA ternyata diperoleh peningkatan hasil dari siklus 1 ke siklus 2. Peningkatan yang peneliti temukan tersebut sejalan dengan apa yang dikemukakan oleh Mimi bahwasannya penggunaan media video pembelajaran mampu memberikan respon positif kepada siswa dikarenakan kegiatan yang menarik bagi siswa untuk ditonton secara saksama disertai dengan rasa keingitahuan yang tinggi sehingga membuat siswa termotivasi untuk belajar, dengan begitu diharapkan mampu meningkatkan pemahaman siswa terhadap materi yang dipelajari (2016). Hal ini diperkuat oleh pendapat Yunita \& Wijayanti yang menyatakan jika penggunaan video pembelajaran sangatlah tepat jika diimplementasikan dalam pembelajaran IPA (2017).

Adapun perbandingan peningkatan pelaksanaan pembelajaran dengan penerapan video pembelajaran IPA dapat dilihat pada diagram berikut ini.

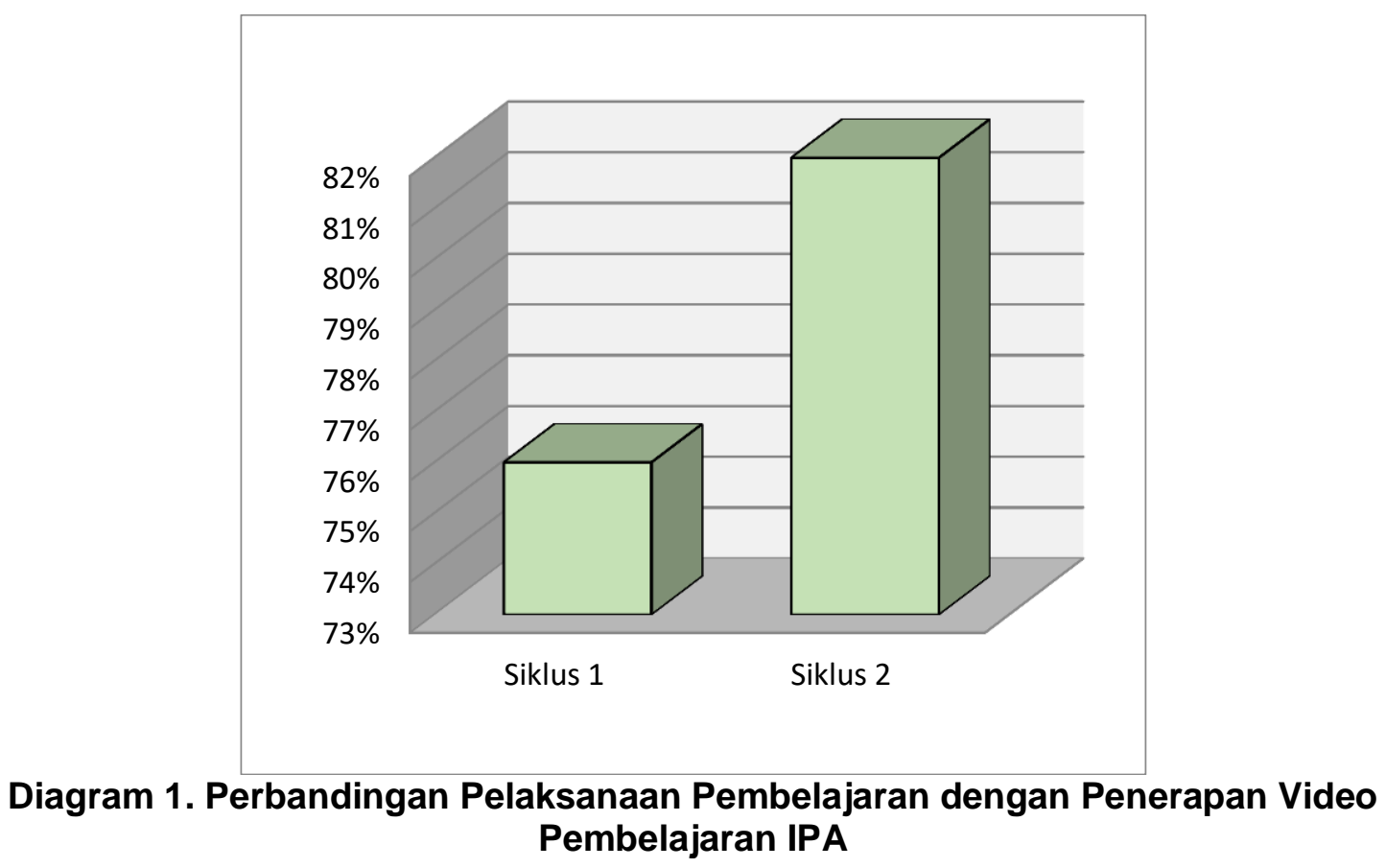

Peningkatan juga peneliti temukan pada ketuntasan hasil belajar siswa secara klasikal dari siklus 1 ke siklus 2 . Hal ini sejalan dengan pendapat Setiawan yang menyatakan bahwa penggunaan media pembelajaran dimaksudkan sebagai perantara untuk menciptakan suatu kondisi lingkungan belajar yang dapat menunjang tercapainya tujuan pembelajaran yang diwujudkan dalam bentuk hasil belajar siswa (2017). 
Adapun perbandingan peningkatan ketuntasan hasil belajar siswa secara klasikal dapat dilihat pada diagram berikut ini.

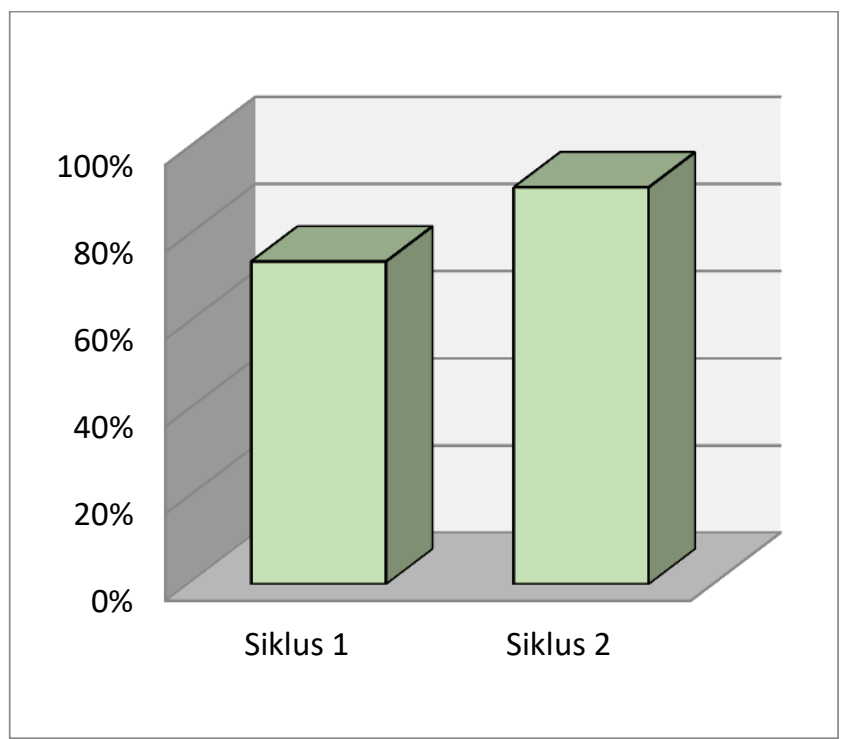

\section{Diagram 2. Perbandingan Ketuntasan Hasil Belajar Siswa secara Klasikal}

Berdasarkan acuan data-data yang disajikan di atas, maka penelitian ini dinyatakan berhasil dan berhenti sampai pada siklus 2 .

\section{SIMPULAN}

Berdasarkan hasil penelitian dan pembahasan yang telah dilakukan, maka peneliti dapat menyimpulkan bahwa (1) Pelaksanaan pembelajaran dengan penerapan video pembelajaran IPA mengalami peningkatan dari siklus 1 sebesar $76 \%$ ke siklus 2 sebesar 82\%; dan (2) Terjadi peningkatan ketuntasan hasil belajar siswa kelas $\mathrm{V}$ secara klasikal setelah penerapan video pembelajaran IPA dari siklus 1 sebesar $74 \%$ ke siklus 2 sebesar $91 \%$.

\section{DAFTAR PUSTAKA}

Abdullah, R. (2017). Pembelajaran Dalam Perspektif Kreativitas Guru Dalam Pemanfaatan Media Pembelajaran. Lantanida Journal, 4(1), 35. https://doi.org/10.22373/lj.v4i1.1866.

Aisyah, Nyimas, \& dkk. (2010). Pengembangan Pembelajaran Matematika SD. Direktorat Jenderal Pendidikan Tinggi, Depdiknas.

Baharuddin \& Wahyuni, E. N. (2015). Teori Belajar dan Pembelajaran. Ar-Ruzz Media.

Febriani, C. (2017). Pengaruh Media Video terhadap Motivasi Belajar dan Hasil Belajar Kognitif Pembelajaran IPA Kelas V Sekolah Dasar The Effect of Video Media on Learning Motivation and Cognitif Learning Outcomes in Natural Science Subject of the Fifth Grade Students of Elem. Jurnal Prima Edukasia, 5(1), 11-21.

Jamaris. (2013). Orientasi baru dalam psikologi Pendidikan. Ghalia Indonesia.

Kemdikbud. (2020). Panduan Penyelenggaraan Pembelajaran Di Masa Pandemi COVID-19. https://www.kemdikbud.go.id/Main/Blog/2020/06/Buku-Saku-Panduan-PembelajaranDiMasa-Pandemi-Covid19.

Kurniawan, M. I. (2015). Tri Pusat Pendidikan Sebagai Sarana Pendidikan Karakter Anak Sekolah Dasar. Pedagogia: Jurnal Pendidikan, 4(1), 41-49. https://doi.org/10.21070/pedagogia.v4i1.71.

Mimi, K. (2016). the Use of Audio Visual To Improve Listening. English Education Journal (Program Pascasarjana Universitas Negeri Semarang), 7(2), 233-245.

Permendiknas. (2006).

Ramdhani, Ali, M., Muhammadiyah, \& Hilmi. (2015). The Criteria of Learning Media Selection for Character Education in Higher Education. Risky - Analisis Penggunaan Media 
Video.

Risky, S. M. (2019). Analisis Penggunaan Media Video pada Mata Pelajaran IPA di Sekolah Dasar. Sekolah Dasar: Kajian Teori Dan Praktik Pendidikan, 28(2), 73-79. https://doi.org/10.17977/um009v28i22019p073.

Santrock, J. W. T. T. W. (2013). Psikologi Pendidikan. kencana Prenada Media Group.

Setiawan, F. (2017). Upaya Meningkatkan Hasil Belajar Siswa dengan Menggunakan Media Kertas Origami. Jurnal Bidang Pendidikan Dasar (JBPD), 1(2), 78-85. http://ejournal.unikama.ac.id/index.php/.

Sukardi. (2003). Metodologi Penelitian Pendidikan. Jakarta: PT Bumi Aksara.

Susilana, R., \& Riyana, C. (2008). Media pembelajaran: Hakikat, pengembangan, pemanfaatan, dan penilaian. CV. Wacana Prima.

Wisudawati, A. W., \& Sulistyowati, E. (2014). Metodologi Pembelajaran IPA. PT. Bumi Aksara.

Yunita, D., \& Wijayanti, A. (2017). Pengaruh Media Video Pembelajaran Terhadap Hasil Belajar Ipa Ditinjau Dari Keaktifan Siswa. SOSIOHUMANIORA: Jurnal IImiah IImu Sosial Dan Humaniora, 3(2). https://doi.org/10.30738/sosio.v3i2.1614 